Volume 4 Issue 2, 2021

DOI: https://doi.org/10.34050/elsjish.v4i2.14008

Homepage: journal.unhas.ac.id/index.php/jish

\title{
Language Curriculum in America and Indonesia: A Comparative Analysis for Improvement of Indonesian Character Education Practice
}

\author{
Bulqia Mas'ud \\ STAIN Majene, Indonesia \\ Correspondence: bulqiamasud@stainmajene.ac.id
}

\begin{abstract}
This article explores the U.S. English Language Arts Curriculum and Indonesian Language and Literature Curriculum. A comparative analysis is drawn to investigate ideological, cultural, and political economy factors that influence the development of both curricula. In addition, the educational purposes and philosophies that support both curricula are also exposed. Specifically, the discussion of the unstated purposes of the curricula shows an interesting finding. Language and literature curriculum of both countries highlight the importance of citizenship and character education and are integrated in the teaching of the curricula. However, the US language curriculum places a premium on fostering American identity, with an emphasis on increasing learning for professional workforce and career-ready individuals, which will benefit the global economy in the future. Meanwhile, Indonesian language curriculum gives priority to moral and religious instruction. The language and literature teaching are integrated in nation's character building. After analyzing, comparing, and contrasting both curricula, the author found that America successfully instills character education to shape the worldview and characters of its citizens extracted from their clear ideology, while Indonesia is somewhat inexplicable and vague. Therefore, this article shows room for improvement for educators and educational leaders in Indonesia to be clearer in defining which character is best exposed in the curriculum.
\end{abstract}

\section{ARTICLE HISTORY}

Published June 23rd 2021

Check for updates

\section{KEYWORDS}

The U.S. English Language Arts Curriculum, Indonesian Language and Literature Curriculum, Character Education

\section{ARTICLE LICENCE}

(C) 2021 Universitas Hasanuddin Under the license CC BY-SA 4.0

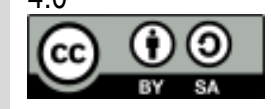

\section{Introduction}

The United States does not adopt national curriculum (Teale \& Thompson, 2014). Hence, the curriculum development, instruction, and content have been spread out throughout the districts or states. This gives full authority to leaders of each state to formulate their own curriculum. In terms of English language arts curriculum, the U.S. covers language and literature teaching (CCSS, 2010) which means teaching both literary and non-literary works. For the past twenty years, what has been maintained in moststates is that the teaching of literature should be reflected to educational standards designed by each state (Teale \& Thompson, 2014). These standards are the ideals of which students should achieve.

Unlike the U.S., which has a local or decentralized curriculum, the Indonesian curriculum is centralized and established by the Ministry of Education and Culture (Ministry of Education and Culture, 2014). Indonesian language and literature curriculum has a strategic role as the foundation of knowledge. To master other knowledge, students should understand the use of the Indonesian language and literature appropriately. Therefore, this essay will explore the similarity and differences of both curricula in secondary school and discuss aspects where curricula could complement each other. Specifically, in my context, I will investigate what can be learned from the U.S. curriculum to improve Indonesia curriculum.

\section{Method}

This study uses descriptive qualitative analysis under the qualitative research approach. This paper describes and compares the phenomenon and characteristics stated in the U.S. and Indonesian Language curricula that seemingly address character education issues. The analysis scrutinizes the U.S. English Language Curriculum based on Common Core State Standards (CCSS) document and Indonesian Language and Literature Curriculum based on the 2013 curriculum document (K-13). Moreover, the literature review is applied to investigate secondary data from academic 
journals, books, and relevant opinions on the newspaper that address the topic. The comparative analysis begins with comparing both curricula in terms of these aspects: 1) the current context of both curricula, 2) what influences the curricula, 3) the educational purposes and philosophies of the curricula, 4) the discussion of unstated purposes of the curricula, 5) and implication for future practice.

\section{Discussion}

\subsection{The Current Context of the U.S. and Indonesia Language and Literature Education}

\section{a. The Curriculum Development}

In 2010, the United States had a slight change in curriculum development. It is the year that the U.S. almost has what is called as national curriculum. Most of the states in the U.S. are encouraged to adopt Common Core State Standards (CCSS) (Teale and Thompson, 2014) established by the Council of Chief State School Officers (CCSSO) and the National Governors Association (NGA) (CCSS, 2010). These standards are meant to aid that all students are college and career ready in literacy (CCSS, 2010). The other difference of the previous standards is now CCSS has provided conduct of literature instruction entire American secondary schools which is called "Reading Standards for Literature for grades 9-12" (Teale \& Thompson, 2014)

The Council of Chief State School Officers (CCSSO) and the National Governors Association build the foundation that is originated from the states' consistency on crafting the local education standards (CCSS, 2010). The standards are designed from intensive research where the sources come from state departments of education, scholars, assessment developers, professional organizations, and educators from kindergarten to college, parents, students, and society (CCSS, 2010). In addition, the CCSS provides a set of goals where states, districts, schools, and teachers will further improve the standards into local curriculum (Jones \& King, 2012). However, schools might adapt the CCSS with a different approach. Since the standards do not specify how teaching should be executed, the contents and instructions are left to the discretion of teachers and curriculum developers (CCSS, 2010). For instance, teachers might use textbooks and literature books that are different with other states'.

Currently, Indonesia has implemented curriculum 2013 (K-13) as the response of low academic competence in the global world. The change is based on learning methods and curriculum arrangement (IIma and Pratama, 2015). Indonesia has implemented a text-based learning in the language and literature curriculum where language is viewed as a text not solely as the group of language rules (IIma and Pratama, 2015). It more represents the values and ideology of the speakers. Since Indonesia is very multicultural, the government gives more authority to the local governments to design their own curriculum in the subject of local wisdom. It is the response of the need of cultural identity and wisdom to shape Indonesian identity. In addition, it is aligned with the development of language and literature curriculum by making use of local literature to preserve the local culture of Indonesia (Rudy, 2008, cited in Inderawati, 2013).

In the process of development, it has no significant change. The curriculum begins with the agreement of national parliament, descend through the ministry of education and culture which involves various educational stakeholders such as scholars, curriculum developers, academic administrators, teachers, parents, and business actors and finally arrive at schools and classroom teachers (Thomas, 1991 cited in Galam, 1997). Ministry of education designs and documents the content standards with the help of educational practitioners, curriculum developers, scholars, school leaders and teachers. The curriculum will be implemented and interpreted by the teachers as the lesson planners, instructors, and evaluators in the classroom. The parents are involved because they monitor the learning activity at home as intended in the curriculum.

\section{b. The Acceptance of the Curricula in the Society}

The existence of this Common Core State Standards brings some reactions from stakeholders. 47 of 50 states have officially adopted these standards (Jones and King, 2012). Massachusetts Board of Elementary and Secondary Education (2016) have strengthened the standards with developing the curriculum, instruction, and assessment on their own. In contrast, Virginia and Nebraska State Board of Education refuse to adopt the standards because both states are on progress of redeveloping the language arts curricula and are still trusted by the local teachers. Another reason for the rejection is the Federal Government aim, which is thought to pursue money rather than excellence (State Education Standard, 2012).

Meanwhile, higher education is very open to this effort. As the standards aim to develop college and carrier readiness, the higher education responds to these standards positively, hence easily tracking the college and worker capabilities. In contrast, marginalized students like autism sufferers react to this standard in the opposite way. The disabled 
people will find this challenging because they are expected to meet the standards while they should still cope with the disability (Marsh, 2015). However, people involved in the business world will be much more interested in the new development of curriculum since it will help the growth of their business by finding capable workers earlier.

Similarly, Indonesian language and literature curriculum under the curriculum 2013 has not yet adopted by all provinces (Sufanti, 2013). Some provinces are still studying the curriculum while others are ready and on progress in implementation. The curriculum brings pros and cons in any educational stakeholders (IIma and Pratama, 2015). One thinks that it does not need changes due to the inconsistency of curriculum labeled in Indonesia educational system. The other thinks that it is a grand design for moral and mental revolution. However, in the goal and practice level, Indonesian society has different approach from that of the United States. If the reformation of the U.S. is more career-oriented, Indonesian society expects the curriculum to be more cultural and moral building oriented (Ministry of Education and Culture, 2014). This concept matters considering all educational practitioners from the policy makers, teachers to parents are concerned to the degradation of morality in Indonesian society. The new curriculum is a hope to instill cultural identity and moral values and shape critical thinking (Ministry of Education and Culture, 2014).

\subsection{Influences on the Curricula}

The curriculum development in each country is also determined by factors that might influence the curriculum. Hence, the influences on curriculum need to be elaborated as they contribute to the design and development of the curricula.

\section{a. Ideology and Culture}

America acknowledges the ideology of American Dream, which was announced for the first time in the Declaration of Independence by Thomas Jefferson (Beach, 2007). Since then, America reformed to become a powerful nation that has certain principles and values. The vision of American Dream introduces the sacred democratic ideals; equality, inalienable rights and life, liberty, pursuit of happiness (property), principle of freedom (Beach, 2007). In the $19^{\text {th }}$ Century, the notion of the American Dream, which encompasses self-reliance, hard-work, success, and prosperity, became the nation's ideology and emerged in the system of school (Beach, 2007).

This ideology becomes a potential and philosophical way for developing and constructing discourse of change in its all aspects including education (Bronfenbrenner, McClelland, Wethington, Moen, \& Ceci, 1996 cited in Beach, 2007). The American dream ideology has always been infused in society, and education becomes the easiest way to indoctrinate the values. English language arts curriculum responds to the values with the existence of new policy, Common Core State Standards, and instigates states to implement the standards. The emerging phenomenon is that the Common Core could be understood to create college and career readiness for students who are money-oriented and envisage the American Dream as one of success perspectives.

In contrast to American values that are more liberal and acknowledge principles of freedom, Indonesia has its unique thought and culture in viewing its societal needs. Even though Indonesian adopts Pancasila as its ideology, it is not crystalized strongly in the society. However, the five principles of Pancasila have become the source of country's values system (Fitch and Webb, 1989). The principles have put forward the importance of moral education. It is also influenced by most society that embraces religions. This is considered as the main significant aspect in life. Therefore, the curriculum always attached to the need of moral, ethical, and spiritual aspects in constructing the curriculum (Ministry of Education and Culture, 2014). Furthermore, since Indonesia is a multicultural country with diverse local culture, Indonesian language and literature curriculum is designed to respond to each area's local wisdom as one way to achieve educational goals. All in all, the curriculum has central position to disseminate and cultivate the expected values in the teaching.

\section{b. Political Economy}

According to Apple (1993) education is broadly affected by the politic of culture. The curriculum is made by purpose that encompasses some interests. It is a group of people's visions and a product of cultural, political, economic compromises and tensions (Apple, 1993). Since the introduction of Common Core State Standards of English language arts curriculum whose goals are to produce college and career ready students, the influence of economic has portrayed in the document. Respond to the economic downward in the U.S., the renewed agreement across America's educational system covers the need for intensive treatment and preparation to succeed in globally competitive economy (Jones and King, 2012). As a result, the Common Core State Standards were developed to regulate educational standards across states and ensure that all students will be prepared for continuing success after completing high school to meet the increasing demands of colleges and businesses of the future. Consequently, capitalism could be grown in this culture of 
education which has become political view of the country. Some literature works adapted in the curriculum combine sociopolitical forces, educational theory, and literary research (Teale and Thompson, 2014). This political economy forces are addressed in the curriculum imaging the U.S. as a country that has political agenda and want to make America great again and not left behind particularly in global economy competition.

The United States and Indonesia are two countries that are socially, politically, and culturally different. Politics and economy in Indonesia also affect the alteration of national curriculum (Rahman, 2018). It is caused by social dynamic and global needs (IIma and Pratama, 2015). For instance, the transformation from curriculum 2006 to curriculum 2013 is the response of PISA assessment result that place Indonesia in lower position. Furthermore, politically, the curriculum transformation is also caused by the change of power (IIma and Pratama, 2015). When the regime changes, the policy also changes following the interests of who owns the power. Nevertheless, politics and the economy have not specifically impacted the core aspects of Indonesian language and literature curriculum since none frequently discourse the issue. Indonesian language and literature education is less discussed and debated in ideological, political, and economic perspective. This is different from the U.S. where politic and economy are interconnected in the education system discourse.

\subsection{The Educational Purposes and Philosophies of the Curricula}

Reading and literature curriculum in the U.S. is expected to create an independent critical thinking (Stotsky, 2013). The activity such as reading literary or non-literary works and writing assignments could broad student analysis and shape their knowledge, which intrigues intellectual growth and increases independent critical thinking (Stotsky, 2013). The students are engaged readers and listeners to understand what an author or speaker is saying and question the author's and speaker's assumption to explore the reasoning (CCSS, 2010). Likewise, language and literature lesson in Indonesia is also directed to increase the capability of critical, logical, creative, and innovative thinking (Ministry of Education and Culture, 2014). However, in the practice level, the U.S. and Indonesia might have different challenge. Western culture which grows with more liberal values is accustomed to the critical thinking concept. Children are even taught to have voices and independence. In contrast, in Indonesian culture, students still give respect to elderly voices as showing politeness. It is socially accepted that parents have control to their children. Hence, there is students' hesitance to communicate their voice, for example in articulating their disagreement. Consequently, this might hamper the critical thinking activity in the class even social life.

With the capability to think critically, the English language arts curriculum in the U.S. provides an integrated literacy model (CCSS, 2010). It emphasizes the skill and instruction in reading, writing, listening and researching to communicate ideas in expository and expressive discourse (Stotsky, 2013). Furthermore, it requires students to gather, comprehend, evaluate, synthesize, and report the ideas and information and write what they read (CCSS, 2010). Thus, it could build the research skill to answer questions and solve problems (CCSS, 2010). Similarly, Indonesian language and literature curriculum is aimed as knowledge and literacy foundation. The curriculum is intended to build high order thinking skills that can help students understand other knowledge (Ministry of Education and Culture, 2014). It is also expected to enhance the literacy skill of students such as to communicate correctly and politely both in in speaking and writing. In addition, the curriculum has now shifted to a text-based learning which language is viewed as text that is not merely as grammatical instruction, but as way to express individual's opinion, attitude, values, and ideology and shape human thinking ability (IIma and Pratama, 2015).

However, the literacy development in English language arts curriculum of the United Stated is intended to be ready for college, workforce training, and life in a technological society (CCSS, 2010). The literacy integration is needed to create highly competitive individual to be proficient in reading complex and informational text from various background for college life and shape capable workforce earlier in a highly competitive world. Meanwhile, Indonesian language and literature curriculum emphasize the literacy development to not only shape knowledge upbringing but also moral understanding. The students are required to be more both knowledgeable and humanized in life.

In addition, there is a long argument that literature has always related to national identity (Applebee, 1974; Frye, 1962; Stotsky, 1994; Willinsky, 1998, 2001 cited in Skerrett, 2010). English language arts curriculum in America prepares them to become self-governing citizens of the U.S. (Stotsky, 2013). They provide students common ground through details of significant works in America cultural history hence the English language arts curriculum can serve as a unifying force in schools and society (Stotsky, 2013). The idea of self-governing citizens sounds individualistic which reflects the identity of strong self-empowerment and actualization. The curriculum purpose is aligned with the nation culture where everyone is urged to achieve dreams as an evidence of accessing the success (Jones and King, 2012). It also teaches to be 
knowledgeable in history and politics which is to analyze recognized works of American literature representing a variety of genres and traditions promoting the philosophical, cultural, political, religious, ethical, and social influences of the historical period that shaped the characters, plots, and settings (California Department of Education, 2000).

Meanwhile, the language and literature curriculum is intended to create religious and well-behaved individual (Ministry of Education and Culture, 2014). Hence, improving moral through literary works is encouraged in Indonesia classroom in which the students can learn various moral lessons of Indonesia literary works. It is expected to shapelndonesian's national and cultural identity that has good characters, religious, social, and knowledgeable traits (Ministry of Education and Culture, 2014). However, it is interesting to explore how educational system in Indonesia that is thought not to solve the problems of moral broken, whereas the character and religious education purposes have been advocating in most curricula.

\subsection{The Discussion of Unstated Purposes of the Curricula}

Some researchers have found similar pattern in the teaching of literature in English language arts classroom across the United States (Teale and Thompson, 2014). They argue that the literary works used in the high school classroom represent the idea of how to be an American or what it means to be American (Loh, 2009 cited in Taele and Thompson, 2014). Even though the United States addresses the goal of being a self-governing citizen of America in the intended curriculum, the concept of "what it means to be American" sounds more ideological yet has not evidently stated. The curriculum attempts to introduce the ideas behind American national identity which has been crystalized in American society for a long time. Unconsciously, the ideology might be smoothly adopted by the citizens.

The expected ideals of American Dreams have been found in some literary works that are discussed in the U.S. high school literature classroom. First, it reflects American dreams, which are pursuit of happiness (property) such as novel Fitzgerald's The Great Gatsby and Arthur Miller's Death of Salesman (Skerrett, 2010). Both literary works talk about a man who firmly believes that property, wealth, and fame are the symbol of success and strive for those dreams. In addition, the American Dream values such as equality, inalienable rights and values, and liberty have been much explored in the historical documents of literary and philosophical significance such as Abraham Lincoln's Gettysburg addressing The Declaration of Independence, Martin Luther King Jr.'s "I Have a Dream" speech, John F. Kennedy's inaugural speech, (Massachusetts Department of Elementary and Secondary Education, 2010).

In addition, the curriculum also implies one of the characteristics of American dreams which nourish democratic ideals. Even though it is not distinctly stated in the curriculum, the researchers have highlighted that there are some literary works that are explored in the classrooms of different states of the United States which uphold democratic ideals such as Sims Bishop's Johnny Tremain and Anthony Burns, Galda \& Beach's Huckleberry Finn (Teale and Thompson, 2014). Furthermore, it also enunciates the principle of freedom and liberal values. Even though not all citizens embrace these values and unstated noticeably in the documents, they successfully familiarize the ideas to students. For example, they bring forward the secular texts which narrate the separation between churches and state in some literary works such as Harper Lee's To Kill a Mockingbird, Arthur Miller's The Crucible, Eli Wiesel's Night about holocaust embedded the criticism of religion (Teale and Thompson, 2014).

However, those secular contents serve as a source of moral instruction (Teale and Thompson, 2014). Interestingly, even though America does not emphasize religion and moral study, students' cultivating of good characters is still maintained in daily life. For instance, the American's ideals and moral teachings are well-crystalized such as successfully instilling discipline, hard work, effort, sustainability, competitiveness etc. However, those moral teachings are not linked to any religions but embedded and taught in their language arts books which are quite ideological-oriented. This is different from Indonesia's educational context where character and religious education have been reassured in each subject due to the high rate of corruption acts. It is also signaled to the Indonesian language and literature curriculum to focus on religious and moral values.

Even though the importance of moral and religious aspects is suggested in the curriculum, character education has not been fully comprehended in Indonesian language and literature education. Since character education is separated in the curriculum, yet expected to integrate into the classroom practice, it becomes elusive and vague. In one hand, it is thought to be essential and should be integrated in all curricula especially literature education, but on the other hand it does not have the definite concept from the intended curriculum. Giving autonomy to teachers to teach and implement the character education might not work since teachers bring different values. Moreover, teachers are confused of how the lesson plans are made while the syllabus is not overt. To solve this problem, character education as an unstated purpose should be considered. 


\subsection{Implication for Future Practice}

Comparing the English language arts curriculum in the United States to the Indonesian language and literature curriculum in Indonesia enlightens my perspective on what can be learnt from the United States curriculum and how it should be adapted for the Indonesian environment. In my educational practice, I want to point out the importance of instilling certain values to students while learning language and literature. I view there is room for improvement in character education in language and literature curriculum in Indonesia after analyzing, comparing, and contrasting both curricula.

English language arts curriculum in the U.S. context is designed with considering the ideological perspective of the country. The Common Core States Standards are made to produce college and career ready students that will contribute to the country's development. The standards might be advantageous in supporting the economic opportunity where students are prepared as resources of profitable business. The business agents might obtain the benefits since the CCSS and higher education work together to enhance learning for professional workforce. In addition, the higher education might also gain advantages since the curriculum will transfer capable and ready high school graduates to enter universities. In other words, it also eases universities to accommodate students' capabilities and match the students with the entry-level courses (Jones and King, 2012). By then, students will be directly streamed in their capabilities and preference hence it eases them in the admission process. However, the implementation of this curriculum should pay attention to the marginal people. Those who loses might be disable people who need more aids and less competent in workforce training.

If the U.S. curriculum gives priority to economic benefit rather than moral instruction, the curriculum is a form of moral instruction in Indonesia context. The teaching might contribute to the development of character education. Some researchers argue that moral and ethical tradition could be transferred in the teaching of literature (Skerrett, 2010). Hence it benefits some academicians and educators especially those who teach language and literature to take part in nation's character building (Inderawati, 2013). Moreover, according to Inderawati (2013), literature has been understood that can help enhance language skills, instigate cultural knowledge and creativity, and instill the information of character (Moody, 1971, Carter and Long, 1991, and Tarigan, 1995). It will be advantageous for students because they can learn good and bad characters through the works of literature. As a result, the understanding and application of the characters might shape their personality.

Nevertheless, teachers in Indonesia are still difficult to interpret and implement the curriculum since it is not intended in any instructions. Teachers might be confused which characters should best taught and are necessary in the teaching. Compared to the values and moral instruction implemented in the American curriculum, although not stated in the curriculum, they successfully instill the ideology in most of society regardless it is good or bad. Highlighting the contents and implementation of the curriculum, this is very interesting finding. America does not have certain religious and moral curriculum and does not emphasize it markedly, but the ideology, moral values, and characters are integrated and instilled through the English language arts curriculum. This might happen because America has defined its ideology explicitly. Then, it is followed by the curriculum design emanated from the ideology. Even textbooks selected and taught in the classroom contain the ideological values, while Indonesia has still rather inexplicable and vague in their concept of ideology.

\section{Conclusion}

Although Indonesia has different contexts, especially in the cultural and belief system, we can still learn from the U.S. It does not mean that we should adopt its values and beliefs. However, Indonesian can learn from the implementation of the English language arts curriculum. America successfully instills character and moral education to shape its citizens' worldview (thought) and characters extracted from their ideology. Furthermore, I highly recommended that educators and educational leaders be clearer in defining which characterhat educators and educational leaders should be clearer in defining which character is best exposed in the curriculum. They should also decide what supported means that ease them from achieving their educational standards, such as using textbooks containing more ideological values, rather than solely teaching grammatical rules. As a higher education teacher and passionate in character education, I want to research more about Indonesian language and literature textbooks since this has not been much explored in this paper and takes an important factor in teaching character education that can help foster Indonesian worldview and personality.

\section{References}

Apple, M. W. (1993). The politics of official knowledge: Does a national curriculum make sense?. Discourse, 14(1), 1-16.

Beach, M. J. (2007). The ideology of the american dream: Two competing philosophies in education, 17762006. Educational Studies: Journal of the American Educational Studies Association, 41(2), 148-164. 
California Department of Education. (1998). English language arts content standards for California public school. California: The California Department of Education. Retrieved from http://www.cde.ca.gov/be/st/ss/documents/elacontentstnds.pdf

Common Core State Standards Initiative. (2010). Common core state standards for English language arts \& Literacy in history/social studies, science, and technical subjects. Washington, DC: National Governors Association Center for Best Practices \& Council of Chief State School Officers. Retrieved from http://www.corestandards.org/wpcontent/uploads/ELA_Standards1.pdf

Fitch, R. M., \& Webb, S. A. (1989). Cultural immersion in indonesia through pancasila: State ideology. Journal of Educational Thought/Revue De La Pensee Educative, 23(1), 44-51.

Galam, R. G. (1997). Curriculum development in indonesia, malaysia, and singapore. Alipato: A Journal of Basic Education, 2(1\&2).

IIma, Z., \& Pratama, R. K. (2015, March). Transformation in Indonesian Language Curriculum: Pros and Cons between KTSP 2006 and Curriculum 2013 in Indonesia. Paper presented in International Conference on Trends in Economic, Humanities and Management (ICTEHM'15), Singapore. Retrieved from http://icehm.org/upload/5097ED0315007.pdf

Inderawati, R. (2013). The application of literature for all and literature across curriculum concept by responding literary works to the enlightenment of character education in Indonesia context. Journal of Teaching and Education, 2(1), 13-24.

Jones, A. G., \& King, J. E. (2012). The common core state standards: A vital tool for higher education. Change: The Magazine of Higher Learning, 44(6), 37-43.

Marsh, W. W. (2015). Common core and the uncommon learner: How autism affects acquisition of common core state standards.Contemporary School Psychology, 19(2), 66-76.

Massachusetts Department of Elementary and Secondary Education. (2010). Massachusetts English language arts curriculum framework working draft. Massachusetts, USA. Retrieved from http://www.doe.mass.edu/frameworks/ela/0610draft.pdf

Ministry of Education and Culture. (2014). Peraturan menteri pendidikan dan kebudayaan tentang kurikulum 2013 sekolah menengah atas/madrasah aliyah. Retrieved from https://suaidinmath.files.wordpress.com/2014/09/3-pmp-b-indsma-allson-1juni2014.pdf

Rahman, F. (2018). The Constraints of Foreign Learners in Reading English Literary Works: A Case Study at Hasanuddin University. Journal of Arts and Humanities, 7(2), 01-12.

Reese, W. J. (1998). American high school political economy in the nineteenth century. History of Education, 27(3), 255265.

State Education Standard. (2012). The voices of non-adopters: Members of the virginia and nebraska state boards of education on why their states did not adopt the common core standards. State Education Standard, 12(2), 45-46.

Skerrett, A. (2010). Of literary import: A case of cross-national similarities in the secondary english curriculum in the united states and canada. Research in the Teaching of English, 45(1), 36-58.

Stotsky, Sandra. (2013). An english language arts curriculum framework for american public schools. Arkansas, United States: The University of Arkansas. Retrieved from http://www.uaedreform.org/wpcontent/uploads/2000/01/Stotsky-Optional_ELA_standards.pdf

Sufanti, M. (2013). Pembelajaran Bahasa Indonesia Berbasis Teks: Belajar dari Ohio Amerika Serikat. Magister Pengkajian Bahasa Pascasarjana Universitas Muhammadiyah Surakarta. Surakarta, Jawa Tengah. Retrieved from https://publikasiilmiah.ums.ac.id/bitstream/handle/11617/3363/2_Pembelajaran\%20Bahasa\%20Indonesia\%20Ber basis\%20Teks\%20Belajar\%20Dari\%200hio\%20Amerika\%20Serikat.pdf?sequence=1

Teale, W.H. \& Thompson, K. (2014, December). Litearature and the U.S. high school: current trends in curriculum, materials, and instruction. Paper presented at Seminario Internacional ¿Qué leer? ¿Cómo leer? Lecturas de Juventud, Santiago, Chile. 